\title{
ANALYSIS OF COCONUT DREGS FIBER CONTENT DUE TO FERMENTATION USING FIBER DEGRADATION BACTERIA FROM PLIEK U
}

\author{
Nisrina Hayati ${ }^{1}$, N Ginting 2 , Yunilas ${ }^{2}$, E Mirwandhono ${ }^{2}$, I Sembiring ${ }^{2}$ \\ 1. Student of Animal Production Study Program Faculty of Agriculture, Universitas \\ Sumatera Utara. \\ 2. Staff of Animal Production Study Program Faculty of Agriculture, Universitas \\ Sumatera Utara.
}

Animal Production Study Program Faculty of Agriculture,

Universitas Sumatera Utara.

Medan 20155, Indonesia

E-mail : nisrinahayati.nh4@gmail.com

\begin{abstract}
The success of livestock business is influenced by the feeding cost which will affect production costs, Therefore, it is needed to find an alternative feeds which has high quality content with relatively low prices. Coconut dregs can be used as an alternative to livestock feeds, but it has high fiber content, so it has low digestibility. It is necessary to conduct a processing of coconut dregs by using fermentation with fiber degradating bacteria. The purpose of this research was to determine fiber content changes (NDF, ADF, and hemicellulose) in coconut dregs after experiencing fermentation process using fiber degradating bacteria from PLIEK U. The method used complete random factorial which was designed with two different factors and three replications. The results of analysis of NDF, ADF and hemicellulose showed that there were interactions on both factors, the highest fiber content (NDF, ADF, and hemicellulose) is on the interaction of $\mathrm{P}_{1} \mathrm{~W}_{1}$ ( $1 \%$ and 3 days), and the lowest fiber content (NDF, ADF, and hemicellulose) was on the interaction of $\mathrm{P}_{3} \mathrm{~W}_{3}$ (5\% and 9 days). It was concluded that the fermentation of coconut dregs using bacteria from PLIEK U could degrade the fiber content of coconut dregs, the more bacteria given and the longer the incubation time, so the fiber content (NDF, ADF, and hemicellulose) more decrease, and the best fermentation treatment was found in $\mathrm{P}_{3} \mathrm{~W}_{3}$ interactions that was fermentation with $5 \%$ inoculum and 9 days incubation.
\end{abstract}

\section{Introduction}

The success of livestock business is influenced by three important aspects which are usually called as the triangle of livestock, namely genetic, feed, and management. Good feed is feed that contains nutrients needed by livestock, safety, has high digestibility, does not compete with humans, and has high palatability, of course it comes from high quality ingredients and usually high quality feed have a high price too. Feed cost influence production cost. Feed is the biggest portion of costs, which is around $70 \%$ in livestock business [1]. Therefore, to achieve good business profits, needs high quality feed but has a relatively low prices. Alternative feed is an additional feed that is processed with the aim of being used as a substitute for certain feed ingredients to save on feed costs. Alternative feed ingredients have been widely used to overcome the high cost of obtaining feed ingredients for protein sources such as fish meal and soybean meal [2]. 
Coconut dregs can be used as an alternative feed, because this waste has potential but has not been utilized optimally, the main problem of coconut pulp if used as feed ingredients is low crude protein content (4.89\%), crude fat (38.2\%) and high fiber rough (28.72\%) [3].

One of technology to improve the quality of feed ingredients is by fermentation. In general, all fermented products usually contain simple compounds and easy to digest than the original ingredients [4]. microbes that come from their own substrate have a progressive task in degrading the substrate [5]. Microbial exploration from the processed coconut "pliek u" obtained is YNH11 isolate which belongs to cellulolytic bacteria group which is good in degrading cellulose [6].

\section{Material and Methods}

This research was held at the Laboratory of Microbiology, Faculty of Agriculture, University of North Sumatra and the Goat Research Station for Sei Putih Cut. The study lasted for 3 months, starting from May 2018 to July 2018.

The materials used were bacterial isolates YNH11 from pliek $\mathrm{u}$, coconut dregs, materials to rejuvenate bacteria, namely natrium agar (NA), ingredients in making liquid medium consisting of aquadest, mix minerals (NH4NO3 0.5\%, MgSO47H2O 0, 5\%, KCL 0.5\%, FeSO47H2O 0.01\%, CuSO45H2O $0.001 \%$ ) as much as $1 \%, 0.5 \%$ urea, $0.5 \%$ molasses, and $2 \%$ bran [7], and ingredients in the analysis of fiber content (NDF, ADF, and hemicellulose) including ADF solution, NDF solution, H2SO4, boiling water, and alcohol. The tools used in this reasearch are autoclave, test tubes, test tube racks, bunsen, hot plate, needle tubes, scales, plastic $(1 \mathrm{~kg})$, grinder, sintered glass, vacuum pump, oven, desiccator, and Petri dishes.

The research design used was RAL Factorial 3 x 3, with 3 replications.

Factor I : Various doses of bacterial inoculum

$$
\begin{aligned}
& \mathrm{P}_{1}=1 \% \text { inoculum YNH11 } \\
& \mathrm{P}_{2}=3 \% \text { inoculum YNH11 } \\
& \mathrm{P}_{3}=5 \% \text { inoculum YNH11 }
\end{aligned}
$$

Faktor II : Length of incubation (duration of fermentation)

$$
\begin{aligned}
& \mathrm{W}_{1}=3 \text { days } \\
& \mathrm{W}_{2}=6 \text { days } \\
& \mathrm{W}_{3}=9 \text { days }
\end{aligned}
$$

\subsection{Parameters measured}

The parameters measured in this research are the content of NDF, ADF, and hemicellulose from coconut dregs which has been fermented by bacteria from pliek $u$. The Van Soest method is one of the chemical tests to measure the quality of fiber in a feed material by using a detergent solution as its solvent. Based on the testing method developed by Van Soest, the fiber is further grouped into soluble fiber in neutral detergent (NDF), soluble fiber in acid detergent fiber (ADF), hemicellulose, cellulose and lignin. Proximate analysis, NDF and ADF are tests commonly used to determine the quality of a feed ingredient [8].

\subsection{Implementation of Research}

- The first stage is the rejuvenation of degrading bacteria from pliek u, with the initial step is preparing tools and materials, then the tools that will be used in rejuvenating the bacteria are sterilized using an autoclave, after that take the bacteria with a needle and then streaked in natrium agar media, cover the petri dish with plastic wrap, label it and incubate it for 24 hours at room temperature, then make a nutrient solution in erlenmeyer in the form of a liquid medium consisting of distilled water, mix mineral $1 \%$, urea $0.5 \%$, molasses $0.5 \%$, and bran $2 \%$, then take the bacteria that has grown and put it in the liquid medium as a nutrient solution for the bacteria, then shake it using a shaker for 7 days.

- The second stage is fermentation coconut dregs using fiber degrading bacteria from pliek $\mathrm{u}$, which is started by mixing coconut dregs with the bacteria inoculum degrading from pliek u which has been rejuvenated with three doses of use, namely $1 \%, 3 \%$, and $5 \%$, with each of the three replications was put in a plastic bag and incubated at room temperature for 3 days, 6 days and 9 days. Fermented coconut dregs is dried using a $55^{\circ} \mathrm{C}$ oven. after drying each sample is finely ground to flour. 
-The third stage is the analysis of Van Soest to determine the content of NDF, ADF, and Hemicellulose in coconut dregs that has been fermented.

\section{Results and Discussion}

3.1 Neutral Detergent Fiber (NDF)

Results of Analysis of NDF (Neutral Detergent Fiber) content from coconut dregs that has been fermented with bacteria from pliek u, where the reasearch was conducted with 2 factors, namely factor I is a variety doses of bacterial isolates from pliek (P1 1\%, P2 3\% and P3 5\%) and factor II are different fermentation times (W1 3 days, W2 6 days, and W3 9 days) can be seen in Table 1 below:

Tabel 1. Average of NDF (Neutral Detergent Fiber) content, fermented coconut dregs based on the interaction between the dose of bacterial isolates and the duration of fermentation (\%)

\begin{tabular}{lcccr}
\hline \multirow{2}{*}{$\begin{array}{l}\text { Doses of Inoculum } \\
\text { Bacteria (\%) }\end{array}$} & \multicolumn{3}{c}{ duration of Fermentation (days) } & \multirow{2}{*}{ Averages (\%) } \\
\cline { 2 - 4 } & $\mathrm{W}_{1}$ & $\mathrm{~W}_{2}$ & $\mathrm{~W}_{3}$ & 69,76 \\
\hline $\mathrm{P}_{1}$ & $73,33^{\mathrm{Bb}}$ & $69,37^{\mathrm{Bb}}$ & $66,58^{\mathrm{Ba}}$ & 68,20 \\
$\mathrm{P}_{2}$ & $73,01^{\mathrm{Bb}}$ & $68,37^{\mathrm{Bb}}$ & $63,22^{\mathrm{Ba}}$ & 65,89 \\
$\mathrm{P}_{3}$ & $71,48^{\mathrm{Ab}}$ & $66,85^{\mathrm{Ab}}$ & $59,35^{\mathrm{Aa}}$ & \\
\hline Averages (\%) & 72,61 & 68,19 & 63,05 & \\
\hline
\end{tabular}

Information: Different superscripts on the same row and column show very significant differences $(\mathrm{P}<0,01)$.

The results of the variance analysis showed an interaction between bacterial inoculum doses and fermentation duration which had a very significant effect $(\mathrm{P}<0.01)$ on NDF content in fermented coconut dregs. This shows a positive synergy between various doses of bacterial inoculum and the length of fermentation in reducing NDF content in coconut dregs. After further testing, it was seen that the highest NDF level was in the interaction of $\mathrm{P}_{1} \mathrm{~W}_{1}$ (fermentation with $1 \%$ bacterial isolates and fermentation time of 3 days), wich was $73.33 \%$. While the lowest NDF levels were $\mathrm{P}_{3} \mathrm{~W}_{3}$ interactions (fermentation with 5\% bacterial isolates and 9 days fermentation time) which was 59.35\%. Based on these results we can know that the interaction between the largest dose of bacterial isolates and the longest fermentation time $\left(\mathrm{P}_{3} \mathrm{~W}_{3}\right)$ produces the lowest NDF content and the highest decrease in NDF content compared to other interactions, and vice versa. With the decreasing of NDF levels in coconut pulp, it shows that the nutritional quality of fermented coconut pulp is getting better, because by decreasing the fiber content it will increase the digestibility of the feed ingredients and will also increase other nutrient content. With decreasing NDF levels, cellulose cell wall breakdown has occurred so that feed will be more easily digested by livestock [9]. Adding microbes in the fermentation process can increase the nutritional value of the original ingredient, because there is a simple overhaul of the complex material [10].

Based on the results obtained, it is known that the interaction of $\mathrm{P}_{3} \mathrm{~W}_{3}$ produces the lowest NDF level because this interaction occurs with the longest fermentation time of 9 days, meaning that the longer the fermentation time is carried out the lower the NDF level. This is because in a fermentation process there is a breakdown of lignocellulose bonds by microorganisms in fermentation, the longer the fermentation is carried out, the more the lignocellulose bond will be broken. The results of the study [11] showed that the content of NDF and ADF rice straw which was fermented for 15 days was lower when compared to 10 days.

\subsection{Acid Detergent Fiber (ADF)}

Results of Analysis of ADF (Acid Detergent Fiber) content from coconut dregs that has been fermented with bacteria from pliek $\mathrm{u}$, where the reasearch was conducted with 2 factors, namely factor I is a variety doses of bacterial isolates from pliek (P1 1\%, P2 3\% and P3 5\%) and factor II are different fermentation times (W1 3 days, W2 6 days, and W3 9 days) can be seen in Table 2 below: 
Tabel 2. Average of ADF (Acid Detergent Fiber) content, fermented coconut dregs based on the interaction between the dose of bacterial isolates and the duration of fermentation (\%)

\begin{tabular}{lcccr}
\hline \multirow{2}{*}{$\begin{array}{l}\text { Doses of Inoculum } \\
\text { Bacteria (\%) }\end{array}$} & \multicolumn{3}{c}{ duration of Fermentation (days) } & \multirow{2}{*}{ Averages (\%) } \\
\cline { 2 - 4 } & $\mathrm{W}_{1}$ & $\mathrm{~W}_{2}$ & $\mathrm{~W}_{3}$ & 49,81 \\
\hline $\mathrm{P}_{1}$ & $51,84^{\mathrm{Bb}}$ & $49,81^{\mathrm{Bb}}$ & $47,79^{\mathrm{Ba}}$ & 49,15 \\
$\mathrm{P}_{2}$ & $51,57^{\mathrm{Bb}}$ & $49,48^{\mathrm{Bb}}$ & $46,39^{\mathrm{Ba}}$ & 47,10 \\
$\mathrm{P}_{3}$ & $50,05^{\mathrm{Ab}}$ & $48,06^{\mathrm{Ab}}$ & $43,18^{\mathrm{Aa}}$ & \\
\hline Averages (\%) & 51,15 & $49,12^{\mathrm{Ba}}$ & 45,79 & \\
\hline
\end{tabular}

Information: Different superscripts on the same row and column show very significant differences $(\mathrm{P}<0,01)$.

The results of the variance analysis showed an interaction between the dose of bacterial isolates and the duration of fermentation which had a very significant effect $(\mathrm{P}<0.01)$ on the ADF content in fermented coconut dregs. This shows a positive synergy between various doses of bacterial isolates and the length of fermentation in reducing ADF content in coconut dregs. It was seen that the highest $\mathrm{ADF}$ content was in the interaction of $\mathrm{P}_{1} \mathrm{~W}_{1}$ (fermentation with $1 \%$ bacterial isolates and fermentation time of 3 days) which was $51.84 \%$. While the lowest content of ADF was $\mathrm{P}_{3} \mathrm{~W}_{3}$ interaction (fermentation with 5\% bacterial isolates and 9 days fermentation time), which was $43.18 \%$. Based on these results we can know that the interaction between the largest dose of bacterial isolates and the longest fermentation time $\left(\mathrm{P}_{3} \mathrm{~W}_{3}\right)$ produces the lowest $\mathrm{ADF}$ content and the highest decrease in ADF content compared to other interactions, and vice versa. This is because bacterial isolates from the pliek given in the fermentation process can change the cell wall of the plant to be simpler, therefore if more bacteria are given, the more reshaping will occur.

The interaction of $\mathrm{P}_{3} \mathrm{~W}_{3}$ shows the interaction of the largest dose of bacterial isolates with the longest fermentation time, where the longer the fermentation time is carried out the lower the ADF level. This is because in a fermentation process there is a breakdown of lignocellulose bonds by microorganisms in fermentation, the longer the fermentation is carried out, the more the lignocellulose bond will be broken. NDF and ADF content of rice straw which is fermented for 15 days is lower than 10 days [11]. Therefore the best result of the interaction between the dose of bacterial isolates and the duration of fermentation is the interaction of $\mathrm{P}_{3} \mathrm{~W}_{3}$, namely the interaction between the largest dose of bacterial isolates and the longest fermentation time.

After further testing it was seen that the highest hemicellulose level was in the interaction of P1W1 (fermentation with $1 \%$ bacterial isolates and fermentation time of 3 days), which was $21.49 \%$. While the lowest ADF levels were $\mathrm{P}_{3} \mathrm{~W}_{3}$ interactions (fermentation with $5 \%$ bacterial isolates and 9 days fermentation time), ie $16.16 \%$. Based on these results we can know that the interaction between the largest dose of bacterial isolates and the longest fermentation time $\left(\mathrm{P}_{3} \mathrm{~W}_{3}\right)$ produces the lowest hemicellulose content and the highest decrease in hemicellulose content compared to other interactions, and vice versa.

Based on the results obtained, it is known that the interaction of the bacterial isolate dose with the fastest fermentation time $\left(\mathrm{P}_{1} \mathrm{~W}_{1}\right)$ produces higher hemicellulose levels, and vice versa, meaning that the longer the fermentation time is carried out the lower the hemicellulose content. This is because in the fermentation process there is an overhaul of food fiber made by microorganisms that produce cellulase enzymes that can degrade fibrous feed, this is in accordance with the results of the study [12] which states that cellulase enzymes can be used as biocatalysts to degrade rich fibrous feed hemicellulose and cellulose.

\subsection{Hemicellulose}

Results of Analysis of ADF (Acid Detergent Fiber) content from coconut dregs that has been fermented with bacteria from pliek $\mathrm{u}$, where the reasearch was conducted with 2 factors, namely factor I is a variety doses of bacterial isolates from pliek (P1 1\%, P2 3\% and P3 5\%) and factor II are different fermentation times (W1 3 days, W2 6 days, and W3 9 days) can be seen in Table 3 below: 
Tabel 3. Average of hemicellulose content, fermented coconut dregs based on the interaction between the dose of bacterial isolates and the duration of fermentation (\%)

\begin{tabular}{lccrr}
\hline \multirow{2}{*}{$\begin{array}{l}\text { Doses of Inoculum } \\
\text { Bacteria (\%) }\end{array}$} & \multicolumn{3}{c}{ duration of Fermentation (days) } & \multirow{2}{*}{ Averages (\%) } \\
\cline { 2 - 4 } & $\mathrm{W}_{1}$ & $\mathrm{~W}_{2}$ & $\mathrm{~W}_{3}$ & 19,98 \\
\hline $\mathrm{P}_{1}$ & $21,49^{\mathrm{Ab}}$ & $19,56^{\mathrm{Bb}}$ & $18,88^{\mathrm{Ba}}$ & 19,27 \\
$\mathrm{P}_{2}$ & $21,44^{\mathrm{Ab}}$ & $18,89^{\mathrm{Ab}}$ & $17,49^{\mathrm{Ba}}$ & 18,79 \\
$\mathrm{P}_{3}$ & $21,43^{\mathrm{Ab}}$ & $18,79^{\mathrm{Ab}}$ & $16,16^{\mathrm{Aa}}$ & \\
\hline Averages (\%) & 21,45 & 19,08 & 17,51 & \\
\hline
\end{tabular}

Information: Different superscripts on the same row and column show very significant differences $(\mathrm{P}<0,01)$.

The results of the variance analysis showed an interaction between the dose of bacterial isolates and the duration of fermentation which had a very significant effect $(\mathrm{P}<0.01)$ on the content of hemicellulose in fermented coconut dregs. This shows a positive synergy between various doses of bacterial isolates and the length of fermentation in reducing the content of hemicellulose in coconut dregs.

After further testing, it was seen that the highest hemicellulose level was in the interaction of $\mathrm{P}_{1} \mathrm{~W}_{1}$ (fermentation with $1 \%$ bacterial isolates and fermentation time of 3 days), which was $21.49 \%$, decreased ADF content in fermented coconut dregs by 3.36\%. While the lowest ADF levels were $\mathrm{P}_{3} \mathrm{~W}_{3}$ interactions (fermentation with $5 \%$ bacterial isolates and 9 days fermentation time) which was $16.16 \%$, where there was a decrease in the ADF content of fermented coconut pulp by $8.69 \%$. The hemicellulose level in fermented coconut dregs decreases due to the dissolution of some cell wall proteins and hemicellulose in acidic detergent solutions thereby increasing the portion of ADS and causing a decrease in ADF levels which will also reduce hemicellulose levels in these feed ingredients.

Based on the results obtained, it is known that the interaction of the bacterial isolate dose with the fastest fermentation time $\left(\mathrm{P}_{1} \mathrm{~W}_{1}\right)$ produces higher hemicellulose levels, and vice versa, meaning that the longer the fermentation time is carried out the lower the hemicellulose content. This is because in the fermentation process there is a change in fiber of feed ingredients carried out by microorganisms that produce cellulase enzymes that can degrade fibrous feed, cellulase enzymes can be used as biocatalysts to degrade fibrous feed rich in hemicellulose and cellulose [12].

\section{Conclusion}

Coconut dregs fermentation uses bacteria as long as it can degrade the content of coconut pulp fiber, the greater the dose of bacterial inoculum given and the longer the fermentation time will reduce fiber levels (NDF, ADF and Hemicellulose) in coconu In this study the best fermentation treatment was found in the interaction of P3W3 namely coconut pulp fermentation by giving $5 \%$ bacterial inoculum from pliek $u$ and 9 days incubation time. 


\section{References}

[1] Ketaren, P. 2010. Kebutuhan Gizi Ternak Unggas di Indonesia. Bogor. Balai Penelitian Ternak, PO Box 221.

[2] Pamungkas, W. 2011. Teknologi Fermentasi, Alternatif Solusi dalam Upaya Pemanfaatan Bahan Pakan Lokal. Subang. Loka Riset Pemuliaan dan Teknologi Budidaya Perikanan Air Tawar Jl. Raya 2 Sukamandi, Subang 41256.

[3] Hidayati, N., M. C Padaya., S. Suhartini. 2006. Mikrobiologi Nutrisi. ANDI. Yogyakarta

[4] Laelasari dan Purwadaria, T. 2004. Pengkajian nilai gizi hasil fermentasi mutan aspergillus niger pada subtrat bungkil kelapa dan bungkil inti sawit. Biodiversitas, 5(2): 48-51.

[5] Yunilas, Lili Warly, Yetti Marlida., and Irsan Riyanto. 2013. Potency of Indigenous Bacteria from Oil Palm Waste in Degrades Lignocellulose as A Sources of Inoculum Fermented to High Fibre Feed. Pakistan Journal of Nutrition. 12(9) : 851-853.

[6] Yunilas, Nurzainah Ginting, dan Hasnudi. 2017. Probiotik Pliek $U$ sebagai Bioaktivator Pakan Ternak Berbasis Limbah Sawit (Solid). Laporan Akhir Penelitian Dasar. Fakultas Pertanian Universitas Sumatera Utara

[7] Yunilas. 2016. Peran Mikroorganisme Indigenous Yl (Moiyl) sebagai Inokulum Pendegradasi Serat Berbasis Limbah Perkebunan Sawit. Sumedang. Seminar Nasional Peternakan.

[8] Nursiam, I. 2012. Pendugaan Kadar Neuteral Detergent Fiber dan Acid Detergent Fiber pada Pakan Berdasarkan Hasil Analisa Proksimat. Skripsi. Institut Pertanian Bogor. Bogor.

[9] Yunilas. 2009. Bioteknologi Jerami Padi melalui Fermentasi sebagai Bahan Pakan Ternak Ruminansia. Fakultas Pertanian Universitas Sumatera Utara, Medan.

[10] Utomo, R. 2004. Review Hasil Hasil Pertanian Pakan Sapi Potong. Wartazoa Vol. 14 No.3. Th 2004. Hal : $116-124$.

[11] Rusdin, 2009. Kadar NDF dan ADF Jerami Padi Amoniasi yang Difermentasi dengan Trichoderma Viride. Skripsi. Fakultas Peternakan Universitas Mataram, Mataram

[12] Lamid, M. 2008. Optimalisasi Potensi Enzim Xilanase Produksi Mikroba Rumen dalam Biodegradasi Hemiselulosa pada Jerami padi sebagai Strategi Pemberian Pakan Ruminansia. Disertasi. Pascasarjana Universitas Brawijaya, Malang. 